\title{
Front Matter: Volume 9221
}

, "Front Matter: Volume 9221," Proc. SPIE 9221, Remote Sensing and Modeling of Ecosystems for Sustainability XI, 922101 (21 October 2014); doi: $10.1117 / 12.2086912$

SPIE Event: SPIE Optical Engineering + Applications, 2014, San Diego, California, SPIE. United States 


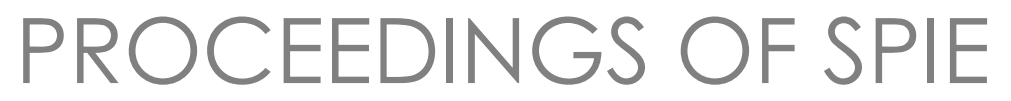

\title{
Remote Sensing and Modeling of Ecosystems for Sustainability XI
}

\author{
Wei Gao \\ Ni-Bin Chang \\ Jinnian Wang \\ Editors
}

18-20 August 2014

San Diego, California, United States

Sponsored and Published by

SPIE 
The papers included in this volume were part of the technical conference cited on the cover and title page. Papers were selected and subject to review by the editors and conference program committee. Some conference presentations may not be available for publication. The papers published in these proceedings reflect the work and thoughts of the authors and are published herein as submitted. The publisher is not responsible for the validity of the information or for any outcomes resulting from reliance thereon.

Please use the following format to cite material from this book:

Author(s), "Title of Paper," in Remote Sensing and Modeling of Ecosystems for Sustainability XI, edited by Wei Gao, Ni-Bin Chang, Jinnian Wang, Proceedings of SPIE Vol. 9221 (SPIE, Bellingham, WA, 2014) Article CID Number.

ISSN: 0277-786X

ISBN: 9781628412482

\section{Published by}

\section{SPIE}

P.O. Box 10, Bellingham, Washington 98227-0010 USA

Telephone +1 3606763290 (Pacific Time) · Fax +1 3606471445

SPIE.org

Copyright @ 2014, Society of Photo-Optical Instrumentation Engineers.

Copying of material in this book for internal or personal use, or for the internal or personal use of specific clients, beyond the fair use provisions granted by the U.S. Copyright Law is authorized by SPIE subject to payment of copying fees. The Transactional Reporting Service base fee for this volume is $\$ 18.00$ per article (or portion thereof), which should be paid directly to the Copyright Clearance Center (CCC), 222 Rosewood Drive, Danvers, MA 01923. Payment may also be made electronically through CCC Online at copyright.com. Other copying for republication, resale, advertising or promotion, or any form of systematic or multiple reproduction of any material in this book is prohibited except with permission in writing from the publisher. The CCC fee code is 0277-786X/14/\$18.00.

Printed in the United States of America.

Publication of record for individual papers is online in the SPIE Digital Library.

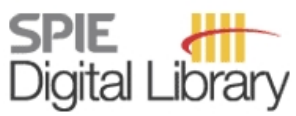

SPIEDigitalLibrary.org

Paper Numbering: Proceedings of SPIE follow an e-First publication model, with papers published first online and then in print and on CD-ROM. Papers are published as they are submitted and meet publication criteria. A unique, consistent, permanent citation identifier (CID) number is assigned to each article at the time of the first publication. Utilization of CIDs allows articles to be fully citable as soon as they are published online, and connects the same identifier to all online, print, and electronic versions of the publication. SPIE uses a six-digit CID article numbering system in which:

- The first four digits correspond to the SPIE volume number.

- The last two digits indicate publication order within the volume using a Base 36 numbering

system employing both numerals and letters. These two-number sets start with 00, 01, 02, 03, 04, $05,06,07,08,09,0 A, 0 B \ldots$. 0Z, followed by 10-1Z, 20-2Z, etc.

The CID Number appears on each page of the manuscript. The complete citation is used on the first page, and an abbreviated version on subsequent pages. Numbers in the index correspond to the last two digits of the six-digit CID Number. 


\title{
Contents
}

\author{
vii Authors \\ ix Conference Committee
}

\section{SESSION 1 REMOTE SENSING FOR AGRICULTURE, ECOSYSTEMS, AND HYDROLOGY}

922103 Hurst exponent for fractal characterization of LANDSAT images [9221-2]

922104 Assimilation of remote sensing data into crop growth model to improve the estimation of regional winter wheat yield [9221-3]

922105 Spatial discretization of distributed hydrological response units for SWAT [9221-4]

922106 Investigation of atmospheric insect wing-beat frequencies and iridescence features using a multi-spectral kHz remote detection system (Invited Paper) [9221-5]

\section{SESSION 2 ENVIRONMENTAL REMOTE SENSING AND GIS}

922108 Optical methods for control of hydrogen influence on plants [9221-14]

9221 OB Calibration of significant wave height from HY-2A satellite altimeter [9221-19]

\section{SESSION 3 REMOTE SENSING AND MODELING APPLICATIONS}

9221 OC Crude oil remote sensing, characterization, and cleaning with continuous wave and pulsed lasers (Invited Paper) [9221-20]

9221 OD Linkages between turbidity levels in Lake Mead associated forest fire events in the lower Virgin watershed (Invited Paper) [9221-21]

9221 OE Study of emissivity behavior in soil through medium infrared range images [9221-22]

9221 OF Evaluation of CALIPSO aerosol optical depth using AERONET and MODIS data over China [9221-23]

9221 OG Spatio-temporal distribution of NDVI and its correlation with climatic factors in eastern China during 1998-2008 [9221-24]

$9221 \mathrm{OH}$ The responses of vegetation water content (EWT) along a coastal region using remote sensing [9221-25] 
$922101 \quad$ Research on construction of Web 3D-GIS based on Skyline [9221-6]

9221 OK Changes of built-up areas at the beginning of the $21^{\text {st }}$ century in Zhejiang Province, China [9221-8]

$92210 \mathrm{~N} \quad$ Assimilation of soil moisture using Ensemble Kalman Filter [9221-13]

9221 OP Geoscience information integration and visualization research of Shandong Province, China based on ArcGIS engine [9221-18]

$92210 Q \quad$ Monitoring the dynamic of suspended sediment using tower-based water spectrum observing system in the Hangzhou Bay [9221-26]

9221 OS Retrieval of total suspended particulate matter in highly furbid waters of Hangzhou Bay using polarizing spectra data [9221-28]

9221 OU Dynamic analysis on coastline and sea reclamation in the region around Bohai based on remote sensing images [9221-30]

9221 OV Nuclear power plants in China's coastal zone: risk and safety [9221-31]

9221 OW Spatial-temporal analysis of coastline changes around Bohai Sea based on remote sensing in recent 20a [9221-32]

9221 OX The study of the spatio-temporal changes of drought in the Mongolian Plateau in $\mathbf{4 0}$ years based on TVDI [9221-33]

9221 OY Retrieval of aerosol optical depth over the Yangtze River Delta with HJ-1 data [9221-34]

$92210 Z$ Retrieval of phycocyanin concentration in the eutrophic Taihu Lake [9221-35]

922110 Analysis of optimal narrow band RVI for estimating foliar photosynthetic pigments based on PROSPECT model [9221-36]

922111 The impacts of bandwidths on the estimation of leaf chlorophyll concentration using normalized difference vegetation indices [9221-37]

922112 The data fusion of aerosol optical thickness using universal kriging and stepwise regression in East China [9221-38]

922114 Analysis on the balance between supply and demand of crop land in Yantai City of China in 2020 [9221-40]

922116 The grain production potential assessment with Multiple Cropping Index $(\mathrm{MCl})$ in $\mathrm{China}$ [9221-42]

922117 Spatial-temporal variability of coastline in Bohai Rim based on fractal dimension [9221-43]

922118 Comparison of the Hargreaves-Samani equation and the Priestley-Taylor equation for estimating reference crop evapotranspiration in the North China Plain [9221-44] 
922119 A WebGIS-based system for analyzing and visualizing air quality data for Shanghai Municipality [9221-45]

9221 1A Estimating leaf photosynthetic pigments information by stepwise multiple linear regression analysis and a leaf optical model [9221-46] 
Proc. of SPIE Vol. $9221922101-6$

Downloaded From: https://www.spiedigitallibrary.org/conference-proceedings-of-spie on 26 Apr 2023 Terms of Use: https://www.spiedigitallibrary.org/terms-of-use 


\section{Authors}

Numbers in the index correspond to the last two digits of the six-digit citation identifier (CID) article numbering system used in Proceedings of SPIE. The first four digits reflect the volume number. Base 36 numbering is employed for the last two digits and indicates the order of articles within the volume. Numbers start with 00, 01, 02, 03, 04, 05, 06, 07, 08, 09, OA, OB...0Z, followed by 10-1Z, 20-2Z, etc.

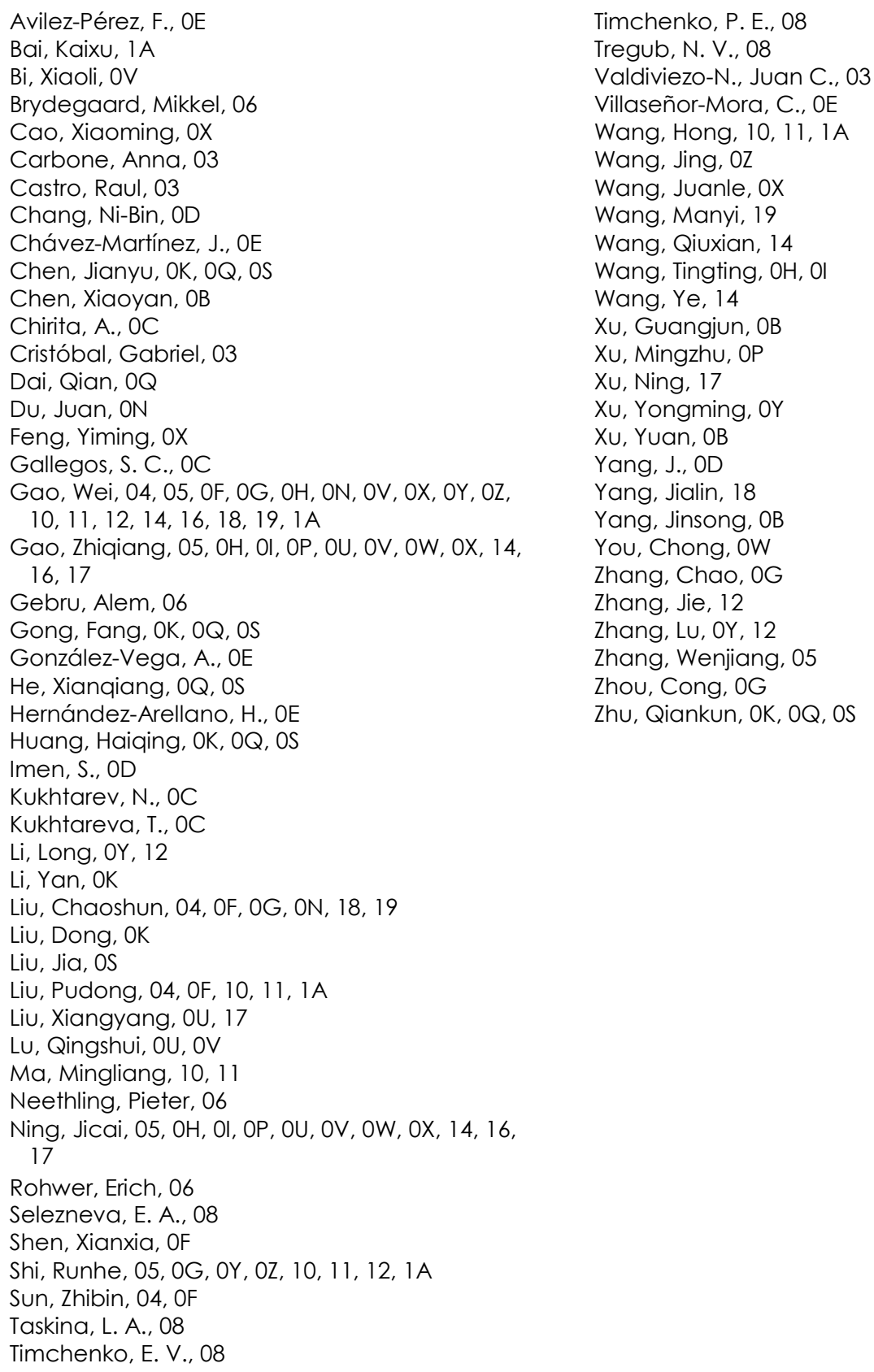


Proc. of SPIE Vol. $9221922101-8$

Downloaded From: https://www.spiedigitallibrary.org/conference-proceedings-of-spie on 26 Apr 2023 Terms of Use: https://www.spiedigitallibrary.org/terms-of-use 


\section{Conference Committee}

Program Track Chair

Allen H.-L. Huang, University of Wisconsin-Madison (United States)

Conference Chairs

Wei Gao, Colorado State University (United States)

Ni-Bin Chang, University of Central Florida (United States)

Conference Co-chair

Jinnian Wang, Institute of Remote Sensing Applications (China)

Conference Program Committee

E. Raymond Hunt Jr., Agricultural Research Service (United States)

Thomas J. Jackson, U.S. Deptartment of Agriculture (United States)

Brian Robert Johnson, NEON, Inc. (United States)

Thomas U. Kampe, NEON, Inc. (United States)

Xin-Zhong Liang, University of Illinois at Urbana-Champaign

(United States)

Dennis Ojima, Colorado State University (United States)

John J. Qu, George Mason University (United States)

David Riaño, University of California, Davis (United States)

Jiong Shu, East China Normal University (China)

Zhibin Sun, Colorado State University (United States)

Qiao Wang, Ministry of Environmental Protection (China)

Hongjie Xie, The University of Texas at San Antonio (United States)

Xiaobing Zhou, Montana Tech (United States)

\section{Session Chairs}

1 Remote Sensing for Agriculture, Ecosystems, and Hydrology

$\mathrm{Ni}$-Bin Chang, University of Central Florida (United States)

Alem Kindya K. Gebru, Stellenbosch University (South Africa)

2 Environmental Remote Sensing and GIS

Xingfa Gu, Institute of Remote Sensing and Digital Earth (China)

Bernd Fichtelmann, Deutsches Zentrum für Luft- und Raumfahrt e.V.

(Germany)

3 Remote Sensing and Modeling Applications

Nickolai V. Kukhtarev, Alabama A\&M University (United States)

Zhibin Sun, Colorado State University (United States) 
Proc. of SPIE Vol. $9221922101-10$

Downloaded From: https://www.spiedigitallibrary.org/conference-proceedings-of-spie on 26 Apr 2023 Terms of Use: https://www.spiedigitallibrary.org/terms-of-use 